\title{
Maternal mourning: pain and coping with the loss of a baby
}

\author{
Luto materno: dor e enfrentamento da perda de um bebê
}

Beatriz Gonçalves Lopes ${ }^{1}$, Pollyanna Kássia de Oliveira Borges ${ }^{1}$, Clóris Regina Blanski Grden ${ }^{1}$, Carlos Eduardo Coradassi $^{1}$, Cibele de Moura Sales ${ }^{2}$, Nauristela Ferreira Paniago Damasceno ${ }^{2}$

Objective: to understand how mothers experienced the experience of their babies' mourning. Methods: this is a qualitative study, conducted with nine mothers who experienced the loss of a child under one year. Semistructured interviews were conducted, and the reports were organized using the Collective Subject Discourse. Results: the participants indicated the complexity and difficulties of the mourning process, implying a grief that lasted but could be overcome through spirituality and family support. They also showed the lack of support from the health services. Conclusion: although mourning is a complex and peculiar process, the mothers pointed out the importance of the spirituality and support of their relatives, but highlighted the lack of support from the health services.

Descriptors: Infant Mortality; Grief; Mother-Child Relations.

Objetivo: compreender como mães vivenciaram a experiência de luto de seus bebês. Métodos: estudo qualitativo, realizado com nove mães que vivenciaram a perda de uma criança menor de um ano. Foram realizadas entrevistas semiestruturadas e os relatos foram organizados utilizando o Discurso do Sujeito Coletivo. Resultados: indicaram a complexidade e as dificuldades do processo de luto, implicando um luto que perdurava, mas que poderia ser superado através da espiritualidade e do apoio familiar. Evidenciaram ainda a ausência de apoio dos serviços de saúde. Conclusão: apesar de o luto ser um processo complexo e peculiar, as mães apontaram a importância da espiritualidade e do apoio de seus familiares, mas destacaram a falta de apoio dos serviços de saúde.

Descritores: Mortalidade Infantil; Pesar; Relações Mãe-Filho.

\footnotetext{
${ }^{1}$ Universidade Estadual de Ponta Grossa. Ponta Grossa, PR, Brazil.

${ }^{2}$ Universidade Estadual de Mato Grosso do Sul. Dourados, MS, Brazil. 


\section{Introduction}

The reaction to death is understood as mourning, and its duration and confrontation are variable according to culture, thoughts, and individuality ${ }^{(1)}$. The most recent conception considers mourning as an inherent process of life ${ }^{(2)}$. However, although it is a certainty in everyone's life, death must be understood as a unique event and mourning as a period peculiar to each of those who have lost a loved one, since this period allows the elaboration and resignification of the relationship with the person who is gone. Thus, for each person, mourning will be felt in a very particular way and will depend on the available support network, the life history of the bereaved, their beliefs and other factors ${ }^{(3)}$.

In the case of maternal-infant mourning, the object of this article, early and unexpected loss can compromise the mother's affectivity, cognition, and behavior, enhancing the effects of mental suffering, affecting bonding and impacting various spheres of life. In this way, mothers lose the child and the life they have planned for them, so thinking about the future after the loss is distressing and difficult ${ }^{(4)}$.

In this context, health professionals play an essential role in the support network for these mothers, and it is important that they be prepared to offer the reception and care demanded by those who experience this suffering, and to clarifying doubts and guiding their families.

Mourning is a process composed of phases not necessarily successive, compulsory or conclusive for all who experience it, but whose knowledge could become a tool to support the bereaved and those who accompany him ${ }^{(5-6)}$. The first phase of mourning would be negation, in the case of infant deaths, at this stage, the mother would avoid reality, she would feel as if she were not experiencing it as if it were a nightmare. Later, she would feel angry and ask, "Why me? Why with me?". Without answers, the third phase of the bargain would begin, in which the mother would try to negotiate, usually with God, to get her child back. In the fourth phase, there is depression; mothers would experience the sadness and emptiness of loss. Then, they enter the last phase of acceptance in which mothers could experience reality, still with much suffering, but being able to join efforts to face it and, day by day, move on ${ }^{(5)}$.

Considering that there are few investigations about the maternal mourning of infants in the national literature, this study proposed to understand the following problem: how do mothers face the death of their children under one year old? What are the supports, according to the maternal perspectives? Therefore, this research was developed with the purpose of understanding how mothers experienced their babies' grief.

\section{Methods}

A case series study with a qualitative approach and cross-sectional design was carried out between 2006 and 2014, with a group of mothers who lost children from 0 to 364 days old in a territory of Ponta Grossa, PR, Brazil, in which there was a teaching service partnership in maternal and child care. The period analyzed corresponded to the time interval for which the Municipal Epidemiological Surveillance had information about infant deaths, such as location data and contact with the bereaved family, the basic cause of the baby's death and the date of death.

From this information, it was found that 14 mothers of the surveyed territory had lost children under one year old. There were five of these mothers with information losses due to change of address or absence of telephone contact $(n=4)$ and rejection of participation in the study ( $n=1)$. Thus, a group of nine mothers participated in the study. Home visits were held to present the research and schedule the interview.

The interviews lasted around 1 hour, and they were conducted from the following guiding questions: How did you face the death of your child? Did someone support you in coping with mourning? From these other issues were being made. The interviews were recorded and transcribed. 
The Collective Subject Discourse (DSC), based on the Theory of Social Representations was used as a technique for tabulation and organization of collected data. This technique is based on the identification of significant aspects of the individual reports and their organization in a single collective discourse. In this way, passages or words that stand out in the individual discourses, called as key expressions, are identified and indicate the consensus between the individuals and the most important aspects of the speeches. Then, the Central Ideas that come out of the reading of the key expressions are summarized and point to the common or divergent conceptions of the discourses. Finally, individual discourses are grouped according to the Common Central Ideas to obtain a discourse of the collective in the first person singular. In this way, the mothers' thinking was presented as if it were a single discourse ${ }^{(7)}$.

The study complied with the formal requirements contained in the national and international regulatory standards for research involving human beings.

\section{Results}

Regarding the socio-demographic conditions, the interviewees were mostly married $(n=4)$, the housewives $(n=5)$, the mean age of 28 years old, incomplete elementary school $(\mathrm{n}=3)$ or complete high school ( $n=3)$. Infant deaths occurred, on average, within 57 days of the child's life.

When talking about the mourning process, the mothers indicated two central ideas: It was very difficult, and mourning persists (Figure 1). Regarding the difficulty felt in the process of mourning, key expressions such as "it was not easy," "I did not face it easily," "it was difficult," "it was very difficult," were repeatedly mentioned in the maternal testimonies. Otherwise, the permanence of mourning was observed several times in maternal discourses through key expressions such as "mourning? Well say the whole life" "we carry it forever," "it always goes on," "I will always remember it."

\begin{tabular}{|c|c|}
\hline Central Idea & Collective Subject Speech - DSC \\
\hline $\begin{array}{l}\text { It was very } \\
\text { difficult }\end{array}$ & $\begin{array}{l}\text { DSC } 1 \text { - As I can say, it was not easy, I did not face it easily, it was difficult, it was very difficult, I felt very shaken, it is a } \\
\text { very strong lost, it is sadness that is inexplicable, it is a very great pain. I only cried all day; I got up crying, I did not know } \\
\text { what to do. You know, I often cried hidden for no one to see, this is bad even to explain, I cannot explain, every day I miss } \\
\text { a piece. For the first few days, I just wanted to sleep, to be locked in the bedroom to forget, I did not think I could handle } \\
\text { it. If an hour I sit down and stop, everything comes to remembrance; it is not easy, we do not forget. I received this news } \\
\text { as they took my feet off the ground, something you do not want for anyone, a pain that is unbearable. In fact, he is gone, } \\
\text { and we have to settle for it. That happens, right?! There is a feeling of sadness, empty that remained. It's very difficult, } \\
\text { you may have others, but it's not the same thing. I tried not to be alone, so I did not think much, but it was difficult, not } \\
\text { something that is so easy to overcome. }\end{array}$ \\
\hline $\begin{array}{l}\text { Mourning } \\
\text { persists }\end{array}$ & $\begin{array}{l}\text { DSC } 2 \text { - If I tell you that bereavement lasts practically until today because there is no way, sadness always, always, } \\
\text { always will be together. Well said, for the whole life! Because that does not end there. We carry it forever. Always when I } \\
\text { remember, I cry because this is something that does not get over so easy. There is no way you could stop and say that our } \\
\text { son left because he was an angel. I cannot explain it... I'll always remember him. The mourning lasts until today [and] I } \\
\text { believe that it continues always. }\end{array}$ \\
\hline
\end{tabular}

Figure 1 - Central Ideas and Discourses of the Collective Subject related to the process of maternal mourning 
On the other hand, the interviewees were questioned about the support received after the child died. From the maternal testimonies, three central ideas emerged: support of beliefs and faith; Family support; Absence of support from the health services (Figure 2).

Regarding support for beliefs and faith, key expressions such as "God's will" "I did not have psychological support, my support was God," "God helped me" were observed in the maternal speeches. Also, in the central idea about family support, the key expressions that most emphasized were "the whole family," "my whole family was on my side." Moreover, regarding the lack of support from the health services, the key expressions they showed were "the unit only said sorry," "from the health unit no one came to see me," "psychological help, I had nowhere practically." The central ideas and the respective Collective Subject Discourse are presented in Figure 2.

\section{Discussion}

Being a study that reports the event of mourning in a series of cases, with cross-cut, the study does not allow causal inference about maternal mourning. It also has the limitation of reporting the specific situation of the group of mothers studied, and the results could not denote the mourning of all the mothers who pass through the death of their babies.

However, as the maternal mourning has been studied under the eyes of those who have experienced it, the results of this research contribute to drawing the attention of other researchers on the subject as well as those caring for families who may be involved in the event of child death. Also, the findings of this study allow the elaboration of hypotheses about the experience of maternal mourning and modes of support to mothers. Therefore, this research may apply to the understanding of the subjectivities involved in

\begin{tabular}{|c|c|}
\hline Central Idea & Collective Subject Speech -DSC \\
\hline $\begin{array}{l}\text { Support of beliefs } \\
\text { and faith }\end{array}$ & $\begin{array}{l}\text { DSC } 3 \text { - So, we have a lot of faith in God, at all times we believed that the will of God would happen for the better, it } \\
\text { was only faith in God that relieved our heart of pain. Just asking God to help me and it was Him that helped me, He } \\
\text { does not give something that you can not carry. I went too much to the religious side, God is not, it was God's will } \\
\text { because if I did not perhaps I could not take it, I got more attached to God to endure because it is difficult to lose a } \\
\text { child. These are things that we have to put in the hands of God and ask for strength is not. God did not do my will; God } \\
\text { wanted to prove that nothing is the way we want it. I always thought, "Oh my God, whatever God wants, if it's to stay } \\
\text { with me, God bless! But, God willing, I can not fight. }\end{array}$ \\
\hline Family support & $\begin{array}{l}\text { DSC } 4 \text { - My family helped me a lot, advised me, I told myself not to stay that way, that it was the best, that if I stayed, } \\
\text { it would be worse, right, that God would have taken me. They were afraid I would go into depression, so they talked } \\
\text { a lot. They gave me strength and give me until today if not, it's not the same thing. They said, "You lost that, she went } \\
\text { to God, right?" And you will get others! But none replaces the other's place. }\end{array}$ \\
\hline $\begin{array}{l}\text { Absence of support } \\
\text { from the Health } \\
\text { Services }\end{array}$ & $\begin{array}{l}\text { DSC } 5 \text { - I went to a hospital that should not have gone, I will not say they are guilty, but they do not have that } \\
\text { responsibility know, they have a bit of fault. I in the case blamed the hospital. Sometimes it's a thing to save. If the } \\
\text { doctor had done something by the time he arrived, he had saved him. They did not do anything! In my view, it was } \\
\text { fatal there. That's why I think it was not that God wanted to get her out of me, but I think there was a lot of neglect } \\
\text { in the hospital. In this world, today we need new people who like what they do. The Unit just said, "I'm sorry." Feeling } \\
\text { everyone feels, does not it? At no time did the health unit help me, attention by them I did not have, just staring, they } \\
\text { did not visit me here, but they did. When you lose a child, your psychological is affected. I suffered enough! Probably I } \\
\text { would have a medical, psychological follow-up. Here I had nothing. What I miss is this psychological support, because } \\
\text { mothers who lose their children need support, we do not have ... many mothers do not. }\end{array}$ \\
\hline
\end{tabular}

Figure 2 - Central ideas and Discourses of the Maternal Collective Subject about the support received after the death of the child 
the bereavement process and indicate that there are possibilities for intervention in the various points of the maternal health care network.

In this study, the mothers demonstrated that, in the face of the death of their children, they did not know how to deal with their feelings, they had to hide their suffering and thoughts from the loss they had no way to prepare, corroborating findings from another study ${ }^{(8)}$. Even though these mothers have lived less than a year with their children, the bond between mother and child begins before childbirth; it is a singular process that, depending on the mother's psyche, can begin before pregnancy, so the death of the baby definitely interrupts the idealized project ${ }^{(8)}$. Thus, the mother's adaptation to loss demands unconditional support from those around her, including continued dialogue, affective and receptive to her suffering ${ }^{(9)}$.

The process of mourning is slow, painful and distracts the mourner from activities that are not tied to the lost object, so devotion to mourning leads to loss of interest in the external world ${ }^{(4)}$. However, the strategies used by mothers to cope with the difficult moment of death indicate, in this research, the denial and rationalization of the loss, both consistent with the findings of other studies on maternal mourning ${ }^{(1,10)}$.

Another point that stands out is that in the process of mourning the mothers arrived at a time when it was possible to accept the idea that the incident had occurred and they did not have the power to change that reality ${ }^{(1,4)}$. However, they reinforced that it is possible to elaborate mourning, to learn to live with the physical absence of the child who died but not to eliminate this child from their lives ${ }^{(2)}$. The literature shows that the death of a child can lead to prolonged mourning ${ }^{(1)}$ and that its duration may vary from person to person, in some cases never ending ${ }^{(4)}$, which does not necessarily suggest a pathological mourning, but suffering remains even if they have moved on with their lives.

In the Brazilian context, the population stands out for its religiosity and beliefs ${ }^{(11)}$, a condition contributing to the spirituality becoming a way for mothers to justify or give some meaning to the death of their children, thus fueling hope of a future reunion ${ }^{(12)}$. Moreover, the discourse of mothers, similar to that reported in other national studies ${ }^{(3,10)}$, referred to a way of rationalizing the baby's death by constructing a justification that departs from the divine will, a greater force.

Increasingly allied with the health area, spirituality brings comfort in different moments of life, besides being considered as a preventive factor for the development of diseases ${ }^{(11)}$. In this way, trusting in God's will can be by maternal beliefs, an important strategy for finding comfort, avoiding questioning, avoiding guilt, and replanning life without the child.

It was noted that family members sought to comfort mothers from their beliefs, noting the possibility of gestating other children, worrying about their mental health, and advising them not to prolong their suffering. However, it should be noted that the family is also affected by grief since each member of the family builds expectations and unique bonds about the arrival of the baby. At this juncture, the whole family should be welcomed and guided about the grieving process.

When performed by health professionals, these guidelines may contribute to the family avoiding to offer advice or take actions that favor denial of the severity of the loss or limit the expression of the feelings and fantasies of the mothers. In this type of intervention, considering that there is no prescribed formula for the professional to learn to understand and respect the mourning of the other, professionals are expected to receive training on the subject, seeking to improve on the humanization of $\operatorname{care}^{(3)}$ and available to facilitate the path in the health network by the bereaved user.

When the child dies, health care is terminated ${ }^{(13)}$. But it would be expected to start another cycle of care, in this context, a strategy that could be devised by the health services could be the organization of support groups for mothers who lost children, allowing the sharing of experiences and mutual support among 
women Who experience this suffering(4).

Only a minority of mothers who deal with the mourning of a child present severe psychopathological reactions. However, they all need emotional support with particularity ${ }^{(13)}$. However, work overload in the Basic Health Units, as well as the inability of professionals to assist bereaved mothers, demonstrates the need for matrix supporters of the Family Health Support Center and/or Psychosocial Care Centers for Primary Care teams to ensure that longitudinal care is guaranteed ${ }^{(14)}$.

In general, the nurse is the coordinator of the Primary Health Care health teams, and the professional directly linked to the continuous care of the user. In the systematization of nursing care, the nurse can make the nursing diagnosis, pointing out the degree of dependence of the bereaved mother, and with technical, social and affective skills, she can judge the best intervention in each case.

A qualitative study carried out in prison in Cambridge ${ }^{(15)}$, attended by ten mothers who lost their child, demonstrated that the participants recognized the need for the support offered by other people, such as support groups, health professionals or their family members. Likewise, mothers reported that they did not have effective support and many became addicted to drugs while trying to overcome the loss. On the other hand, a qualitative research with a phenomenological approach carried out by 19 employees of a hospital in Córdoba, Spain ${ }^{(16)}$, showed that health professionals lacked the skills and resources to approach mourning, requiring great emotional competence, and did not have awareness that an inadequate professional attitude can compromise the evolution of the parents' mourning.

Besides the absence of support from the health unit after the baby's death, the participants in this study pointed out the possibility of hospital neglect. Infant mortality has been declining in Paraná, but a large proportion of these deaths would still be avoidable, which may be indicative of a low level of health services ${ }^{(17)}$. On the other hand, in the last years, the management of the services has implemented strategies to increase quality care for pregnant women and newborns ${ }^{(18)}$.

It may also be considered that the mothers' report on the neglect of health professionals may also be due to feelings of incapacity, the need to attribute guilt, or revolt at the loss of the child ${ }^{(8)}$, a form of defense through denial and/or rationalization. However, this report reinforces the important role of health professionals in listening and receiving the mother and the next of kin. In the absence of this work, still in the hospital or in continuous follow-up, fantasies arising from doubts can proliferate, and these fantasies can give vent to the need to find an explanation as assumptions reported in the speech.

\section{Conclusion}

The mothers' report enabled to identify the complexity, particularity and long duration of the process of maternal mourning by their babies. In this process, the mothers pointed out the importance of spirituality and the support of their relatives but highlighted the lack of support from the health services.

\section{Collaborations}

Lopes BG and Borges PKO contributed in the design and project and the analysis and interpretation of the data. Grden CRB, Coradassi CE, Sales CM and Damasceno NFP contributed in the writing of the article, relevant critical review of the intellectual content and final approval of the version to be published.

\section{References}

1. Muza JC, Sousa EN, Arrais AR, Iaconelli V. Quando a morte visita a maternidade: atenção psicológica durante a perda perinatal. Psicol Teor Prat. 2013; 15(3):34-48. 
2. Faria-Schutzer DB, Lovorato Neto G, Duarte CAM, Vieira CM, Turato ER. Fica um grande vazio: relatos de mulheres que experienciaram morte fetal durante a gestação. Est Inter Psicol [Internet]. 2014 [citado 2017 abr 09]; 5(2):113-32. Disponível em: http://dx.doi.org/10.5433/22366407.2014v5n2p113

3. Lemos LFS, Cunha ACB. Concepções sobre morte e luto: experiência feminina sobre a perda gestacional. Psicol Ciênc Prof [Internet]. 2015 [citado 2017 abr 09]; 35(4):1120-38. Disponível em: http://dx.doi.org/10.1590/19823703001582014

4. Freitas JL, Micheal LHF. A maior dor do mundo: o luto materno em uma perspectiva fenomenológica. Psicol Estud [Internet]. 2014 [citado $2017 \mathrm{abr}$ 09]; 19(2):273-83. Disponível em: http://dx.doi. org/10.1590/1413-737222324010

5. Silva S, Carneiro MIP, Zandonadi AC. O luto patológico e a atuação do psicólogo sob o enfoque da psicoterapia dinâmica breve. Rev Farol [Internet]. 2017 [citado 2017 abr 15]; 3(3):14357. Disponível em: http://www.revistafarol.com. br/index.php/farol/article/view/42/63

6. Taverna G, Souza W. O luto e suas realidades humanas diante da perda e do sofrimento. Cad Teol PUCPR. 2014; 2(1):38-55.

7. Figueiredo MZA, Chiari BM, Goulart BNG. Discurso do Sujeito Coletivo: uma breve introdução à ferramenta de pesquisa qualiquantitativa. Distúrb Comum. 2013; 25(1):129-36.

8. Silva JDD, Sales CA. Do imaginário ao real: a experiência de pais enlutados. Rev Rene. 2012; 13(5):1142-51.

9. Farias LM, Freire JG, Chaves EMC, Monteiro ARM. Enfermagem e cuidado humanístico às mães diante do óbito neonatal. Rev Rene [Internet]. 2012 [citado 2017 abr 15]; 13(2):365-74. Disponível em: http://www.periodicos.ufc.br/ index.php/rene/article/view/3928

10. Cremasco MVF, Schinemann D, Pimenta SO. Mães que perderam filhos: uma leitura psicanalítica do filme Rabbit Hole. Psicol Cienc Prof [Internet]. 2015 [citado 2017 abr 9]; 35(1):54-68. Disponível em: http://dx.doi.org/10.1590/19823703002152013
11. Henning-Geronasso MC, Moré CLOO. Influência da religiosidade/espiritualidade no contexto psicoterapêutico. Psicol Cienc Prof [Internet]. 2015 [citado 2017 abr 09]; 35(3):711-25. Disponível em: http://dx.doi.org/10.1590/19823703000942014

12. LimaS, Fortim I. A escrita como recurso terapêutico no luto materno de natimortos. Rev Latino-am Psicopat Fund [Internet]. 2015 [citado 2017 abr 09]; 18(4):771-88. Disponível em: http://dx.doi. org/10.1590/1415-4714.2015v18n4p771.12

13. Paris GF, Montigny F, Pelloso SM. Factors associated with the grief after stillbirth: a comparative study between Brazilian and Canadian women. Rev Esc Enferm USP. 2016; 50(4):546-53.

14. Castro CP, Campos GWS. Apoio Matricial como articulador das relações interprofissionais entre serviços especializados e atenção primária à saúde. Physis [Internet]. 2016 [citado 2017 abr 9]; 26(2):455-81. Disponível em: http://dx.doi. org/10.1590/S0103-73312016000200007

15. Lewin LC, Farkas KJ. Living with the loss of a child: Mothers in the criminal justice system. Palliat Supp Care [Internet]. 2012 [cited 2016 Dec 10]; 10(4):265-72. Available from: https://doi. org/10.1017/S147895151100099X

16. Montero SMP, Sánchez JMR, Montoro CH, Crespo ML, Jaén AGV, Tirado MBR. Experiences with perinatal loss from the health professionals' perspective. Rev Latino-am Enfermagem. 2011; 19(6):1405-12.

17. Netto A, Silva RMM, Santo MF, Tacla MTGM, Caldeira S, Brischiliari SCR. Mortalidade infantil: avaliação do programa Rede Mãe Paranaense em Regional de Saúde do Paraná. Cogitare Enferm. 2017; 22(1):1-8.

18. Baggio MA, Pereira FC, Guimarães ATB, Caldeira S, Viera CS. Programa Rede Mãe Paranaense: análise da atenção pré-natal em uma regional de saúde. Cogitare Enferm [Internet]. 2016 [citado 2017 abr 09]; 21(3): 1-10. Disponível em: http://dx.doi. org/10.5380/ce.v21i3.45301 